\title{
Effects of mechanical thinning on botrytis bunch rot on Sauvignon blanc wine grapes
}

\author{
Dion C. Mundy ${ }^{1}$, Michael C.T. Trought ${ }^{1}$, Andrew R.G. McLachlan², Susan M. Neal ${ }^{1}$ and Dominic Pecchenino ${ }^{3}$ \\ ${ }^{1}$ The New Zealand Institute for Plant \& Food Research Limited, PO Box 845, Blenheim, New Zealand \\ ${ }^{2}$ The New Zealand Institute for Plant \& Food Research Limited, Private Bag 11600, Palmerston North 4442, \\ New Zealand \\ ${ }^{3}$ Pecchenino Viticultural Consulting, 542 Middle Renwick Rd, Blenheim 7271, New Zealand
}

*Corresponding author: dion.mundy@plantandfood.co.nz

(Original submission received 25 November 2020; accepted in revised form 25 July 2021)

\begin{abstract}
Mechanical fruit thinning could be a practical and cost-effective alternative to hand thinning of Sauvignon blanc grapes to increase quality by reducing yield. Botrytis bunch rot, caused by the fungus Botrytis cinerea, is the main seasonal disease risk for grapes grown in New Zealand but it is unknown if this disease is exacerbated by mechanical rather than manual thinning of the vines. It was hypothesised that the damage caused by mechanical thinning would result in more disease or increase disease pressure than hand thinning or no thinning. Botrytis bunch rot was determined in the field at harvest following mechanical thinning in the 2009, 2010 and 2011 seasons compared with an un-thinned control. In the 2011 season, possible mechanisms that may have influenced disease severity were investigated. The parameters investigated were: bunch openness; berry susceptibility to infection; and percentage of bunch debris infected with Botrytis cinerea. Mechanical thinning resulted in the same or lower observed disease severity compared with the un-thinned control in the 2009, 2010 and 2011 seasons while reducing yield as desired. In all seasons, both heavy and light machine thinning treatments reduced incidence of botrytis compared to the un-thinned control and the heavy machine treatment always reduced disease severity compared to the un-thinned control. Berry susceptibility to Botrytis cinerea was a complex interaction between various factors. Heavy machine thinned berries without wounding and inoculation were significantly less susceptible than the un-thinned control. Further investigation will be required to determine if the significant differences observed in berry susceptibility to infection and total infected bunch debris per bunch can be correlated with observed field disease levels.
\end{abstract}

Keywords yield control, mechanical shaking, disease reduction, New Zealand, residue free disease management, vine trauma

\section{INTRODUCTION}

The ability to reliably mature grapes to optimum soluble solids and ripeness, at any site and across seasons, is important for successful high-quality wine production (Neal et al. 2016). At least two-fold differences in seasonal yields of Sauvignon blanc and Chardonnay have been recorded in New Zealand (Trought 2005). This variability, together with seasonal differences in flowering dates and temperature, will affect the likelihood of fruit achieving adequate ripeness in any year. While environmental influences are difficult to manage in the vineyard, yield can be reduced by strategic crop manipulation. Thinning is a technique where growers remove fruit to allow the remaining berries to develop to the desired ripeness before the end of the growing season. Growers generally prefer to undertake thinning after fruit set, when potential yields have been determined for the coming harvest and yield components such as increased berry size cannot compensate for the yield reduction (Neal et al. 2016; Trought et al 2014; Trought et al 2015).
Mechanical thinning of grapes was first used on Concord juice grapes in the USA (Pool et al. 1993) and more recently in both Australia and Europe on red grapes (Petrie \& Clingeleffer 2006; Tardaguila et al. 2008; Tardaguila et al 2012; Diago et al. 2010). Other reports on using mechanical methods of crop load management have focused on reducing labour cost (Bates 2017, Geller and Kurtural 2013) and have not reported interactions between thinning and observed disease.

Botrytis bunch rot, caused by the fungus Botrytis cinerea, is the main seasonal disease risk for grapes grown in New Zealand. In New Zealand's wetter regions, botrytis bunch rot costs the wine industry up to $\$ 5000 /$ ha in direct crop loss and an additional $\$ 1500 /$ ha in disease management costs (Hoksbergen 2010). Under New Zealand conditions, botrytis bunch rot at harvest may be the result of direct or indirect infection of the grape berry during the growing season. The berry can be directly infected at flowering (resulting in latent infections) and again after berry softening during 
ripening (Elmer and Michailides 2007). Within-vineyard epidemics can occur as a result of infection of other grape tissues between flowering and fruit ripening resulting in high potential spore numbers at susceptible stages of berry development under infection conditions for the pathogen (Jaspers et al. 2012). Active management to prevent economic damage to the crop includes preventing physical damage to the skin that can increase berry susceptibility, reducing bunch compactness to allow spray penetration and reducing contact between bunch debris and berries. Removal of dead tissues from within the vineyard on which Botrytis cinerea can grow is also a common practice as part of integrated disease management to reduce the build up of spore pressure (Mundy et al. 2012).

This study was conducted to test the effect of mechanical thinning on a commercial Sauvignon blanc vineyard in Marlborough, New Zealand compared with hand thinning and no thinning. In 2009 and 2010, the aim of the study was to determine if the desired reduction in yield could be conducted using mechanical thinning with no increase in observed botrytis bunch rot. In the 2011 season, possible mechanisms that may have influenced botrytis bunch rot incidence and severity were also investigated. The mechanisms examined were:

1. Mechanical thinning may change the bunch structure by removing parts of the bunch, resulting in a more open bunch with lower disease risk.

2. During mechanical thinning, wounding of the berries may result in changes such as induced resistance or increased skin thickness. These berries may be less susceptible to infection.

3. The mechanical thinning action may remove debris or trash from the bunches, resulting in reduced sources of disease.

\section{MATERIALS AND METHODS \\ Field trial}

The research trial was located on a commercial Sauvignon blanc vineyard in the central Wairau Plains, Marlborough, New Zealand (41 $49^{\prime}$ S; $173^{\circ}$ 92' E). The experiment was a randomised block design each season with the treatments applied to six whole-row replicates in the vineyard. The experimental plots, in each row consisted of four adjacent vines between intermediate posts. All vines had four canes retained after pruning and a similar node number. Different plots within the vineyard were selected each year (2009, 2010 and 2011).

The vines were leaf plucked before thinning and the block was sprayed with Switch ${ }^{\circledR}$ (Syngenta New Zealand; active ingredients $375 \mathrm{~g} / \mathrm{kg}$ cyprodinil and $250 \mathrm{~g} / \mathrm{kg}$ fludioxonil) applied by growers at recommended field rate for botrytis immediately after thinning to minimise any impact of disease on damaged fruit.

Four vine-thinning treatments were used: un-thinned (control); hand-thinned; and heavy or light machine- thinning. Treatments were imposed approximately four weeks after flowering. Machine thinning occurred on 6 January 2009, 13 or 26 January 2010 and 7 January 2011; and hand thinning on 7 January 2009, 14 or 27 January 2010 and 10 January 2011.

For the mechanical thinning, a Nairn 1230 LS machine harvester (Reese Group Ltd, Palmerston North, NZ) was modified to apply the light and heavy machine-thinning treatments. The belts were removed, and wooden panels inserted to enable the fruit to fall to the ground directly beneath the canopy into the herbicide strip. Three beaters were set up on each side of the harvester at a distance of 1.2-1.4 metres above the ground, with a distance between the ends of the beater (pinch) of $50 \mathrm{~mm}$. The machine travelled at a speed of $3.2 \mathrm{~km} / \mathrm{h}$, and the beater speeds were 400 strokes per minute for the light-thinned treatment and 450 strokes per minute for the heavy-thinned treatment. The fruit shaken off the vines by the machine was captured by polythene sheets placed under the plots. Preliminary research indicated that the weight of fruit on the ground after a machine pass represented approximately $50 \%$ of the total yield reduction, the balance largely resulting from bunches retained in the canopy which subsequently shrivelled to dryness. Hand thinning of whole bunches, undertaken the day after machine thinning, removed twice the weight of fruit collected on the polythene sheets with the aim of reducing hand thinned yields to intermediate between the light and heavy thinning treatments. Hand thinning removing whole bunches conducted in this experiment was at least a month before thinning by hand would normally be conducted in vineyards to achieve yield control hence an exact match to final bunch weight in either mechanical treatment was not possible with thinning at this time as bunch and berry growth was still possible between thinning time and harvest All thinning treatments reduced yields in all seasons and details of this and fruit composition will be reported fully separately. A summary of yield differences is provided in Table 1.

Table 1 Effect of method of grape-vine thinning on yield. Values are mean yield per vine (kg).

\begin{tabular}{lccc}
\hline Thinning treatment & \multicolumn{3}{c}{ Assessment date } \\
\hline & 20 March & 9 April & 12 April \\
& $\mathbf{2 0 0 9}$ & $\mathbf{2 0 1 0}$ & $\mathbf{2 0 1 1}$ \\
\cline { 2 - 4 } Un-thinned control & $11.32 \mathrm{c}$ & $10.82 \mathrm{c}$ & $16.28 \mathrm{c}$ \\
Hand thinning & $8.64 \mathrm{~b}$ & $6.86 \mathrm{a}$ & $11.88 \mathrm{ab}$ \\
Light machine thinning & $8.77 \mathrm{~b}$ & $8.50 \mathrm{~b}$ & $12.54 \mathrm{~b}$ \\
Heavy machine thinning & $6.96 \mathrm{a}$ & $8.06 \mathrm{~b}$ & $9.38 \mathrm{a}$ \\
P-value & $<0.001$ & $<0.001$ & $<0.001$ \\
5\% LSD & 1.51 & 0.98 & 2.52 \\
\hline
\end{tabular}

Within a column, means with different letters are significantly different (5\% LSD comparisons). 


\section{Disease incidence and severity}

Harvest assessments for botrytis severity were done in the field on 20 March, 9 April and 12 April of 2009, 2010 and 2011 respectively. All bunches used for field assessment were randomly selected by walking down the row and reaching a hand into the canopy to find a bunch that was then scored by looking at the bunch and turning it over to assess the complete bunch. Botrytis bunch rot incidence was determined by assessing the presence or absence of Botrytis bunch rot (sporulation and/or purple discoloured berries) on 30 randomly selected bunches (15 on each side of the row) used for severity assessment. Botrytis bunch rot severity for the whole bunch was assessed by visually estimating the percentage of infection using the same criteria as for incidence on each bunch using standard methods for Marlborough (Beresford et al. 2006). Incidence was then compared among the treatments using a binomial generalised linear model (GLM) with a logit link. Comparisons among the treatment means were made using contrasts and the results are presented with $95 \%$ confidence intervals. The results from each sample date were analysed separately. In order to equalise the variances, the percentage severity values were logit-transformed, $\mathrm{Y}=\ln ((\%$ severity $) /(100$ - \%severity $))$, except for any values of zero which were transformed using an empirical logit transformation, $Y=\ln ((\%$ severity + 0.05) / (100.05 \%severity)). The severity of botrytis was then compared among the treatments using analysis of variance (ANOVA). Comparisons among the treatment means were made using $5 \%$ least significant differences (LSD) and the results given as back-transformed means. Statistical analysis of all data was undertaken using Genstat ${ }^{\circledR}$ version 12.

\section{Bunch openness at harvest - 2011}

Fruit from each plot was placed into bins at harvest and yields recorded (Table 1), and ten bunches of grapes from each replicate and each treatment (240 bunches in total) were randomly collected from the top of the bins for subsequent volume assessment. Each bunch was weighed and the length and diameter at the widest part of the bunch measured. The length and diameter were used to calculate a bunch volume by assuming that the bunch had a conical shape (Shavrukov et al. 2004). The volume was calculated using, $V_{\text {calc }}=\pi r^{2} \mathrm{~L} / 3$ (where $r=$ radius of base of bunch, $L=$ length of bunch). The actual volume occupied by the bunch, $\mathrm{V}_{\text {actual, }}$, was determined by measuring the water displacement for each bunch. A measure of bunch openness was obtained from the ratio of the actual volume to calculated volume (Ratio $=\mathrm{V}_{\text {actual }}$ / $\mathrm{V}_{\text {calc }}$ ). The water displacement method proved to be slow, so the calculated method was used on all treatments. However, to validate the calculated method of bunch compactness with the displacement protocol, the compactness of 120 bunches from the control and heavy thinning treatments were calculated using both methods and compared using a Student t-test.

\section{Berry botrytis susceptibility assay - 2011}

Bunches were harvested from the two most extreme thinning treatments (control and heavy mechanical thinning) and tested for susceptibility to botrytis. Individual berries were removed from bunches and surface sterilised in $70 \%$ ethanol for one minute (Mundy \& Beresford 2007). Half the berries were then wounded by breaking the skin with a sterile mounted needle ( $1 \mathrm{~mm}$ wide) using the method of Mundy \& Beresford (2007). Half of all the berries, wounded or not, were then inoculated with a $20 \mu \mathrm{L}$ drop of $B$. cinerea containing $\sim 1-5 \times 10^{4}$ spores from mixed cultures produced in the lab from field isolates collected from grapes. Noninoculated controls received the same amount of distilled water. Thus, the three treatment factors: thinning (control or heavy mechanical), wounding (no or yes), and inoculation (no or yes) produced eight factorial treatment combinations. Because the thinning treatment was replicated six times in the field and then the wounding and inoculation laboratory treatments were applied to each of those field replicates, the experiment was conducted as a split-plot factorial design, with the thinning treatments applied to 'main plots' and the $2 \times 2$ factorial combinations of wounding and inoculation applied to 'sub plots'. The berries from each laboratory treatment were placed together in groups of 10 on small covered plastic trays for incubation with no berries touching; there were 10 trays (100 berries) for each replicate. After incubation of seven days at $20^{\circ} \mathrm{C}$, the disease incidence was determined by assessing the presence or absence of botrytis on each berry under a dissecting microscope. In total 4800 berries were assessed ( 8 treatment combinations $\times$ 6 replicates $\times 100$ berries/replicate). Results were analysed for the incidence of $B$. cinerea using ANOVA after first logittransforming the percentages.

\section{Bunch debris assessment and incubation - 2011}

Twenty-five bunches of grapes were collected from each replicate from each treatment (300 bunches in total). Each bunch was disassembled and the pieces of debris (flower parts, aborted berries and other dead material which was not part of the intact berries such as rachii and leaf fragments) within the bunch counted and then separately incubated in a sealed plastic container $17 \times 11 \mathrm{~cm}$ wide and $8 \mathrm{~cm}$ deep. The debris pieces were placed so that they did not touch each other along with a moist paper towel in an air-conditioned lab set at $20^{\circ} \mathrm{C}$ for seven days to determine if there was $B$. cinerea present on the debris. The results for the 25 bunches from each replicate were averaged for analysis. The means from the control and the heavy thinning treatments were compared using a Student t-test.

\section{RESULTS}

\section{Yield 2009 - 2011}

Seasonal differences in yield were observed between treatments (Table 1). It is also important to note that as the vines used are part of a biological system control yield was not constant in all three seasons with an average of $16.28 \mathrm{~kg}$ per bay yield in 2011 control compared to the $11.32 \mathrm{~kg}$ and $10.82 \mathrm{~kg}$ yields in the other two seasons. All of the thinning treatments always achieved a significantly lower yield than the control in the year they were applied (Table 1). The relative harvest yield achieved in March or April from the application of thinning in January was not always consistent. In 2010, hand thinning resulted in the 
lowest yield per vine but, in the other two seasons, heavy machine thinning reduced the yields to the lowest average per vine.

\section{Bunch volume - 2011}

The bunch weight and measured volume was greater in the control grapes than in the heavily thinned grapes in the one year tested (2011) (Table 2). The ratio of actual volume to calculated conical volume did not differ significantly between bunches from the two thinning treatments $(P=0.67)$.

Table 2 Effect of method of grape-vine thinning on aspects of grape bunch architecture in 2011.

\begin{tabular}{lccc}
\hline $\begin{array}{l}\text { Thinning } \\
\text { treatment }\end{array}$ & $\begin{array}{c}\text { Bunch } \\
\text { weight } \\
\text { (g) }\end{array}$ & $\begin{array}{c}\text { Calculated } \\
\text { volume } \\
\text { (mL) }\end{array}$ & $\begin{array}{c}\text { Actual bunch } \\
\text { volume } \\
\text { (mL) }\end{array}$ \\
\hline Un-thinned control & $158.7 \mathrm{c}$ & $150.3 \mathrm{c}$ & 140.5 \\
$\begin{array}{l}\text { Hand thinned } \\
\begin{array}{l}\text { Light machine } \\
\text { thinned }\end{array}\end{array}$ & $148.7 \mathrm{c}$ & $135.4 \mathrm{bc}$ & - \\
$\begin{array}{l}\text { Heavy machine } \\
\text { thinned }\end{array}$ & $102.8 \mathrm{~b}$ & $120.9 \mathrm{ab}$ & - \\
$P$-value & $106.1 \mathrm{a}$ & 97.4 \\
\hline
\end{tabular}

Within a column, means with different letters are significantly different ( $5 \%$ LSD comparisons). 10 bunches from each of $n=6$ replicates.

\section{Disease incidence 2009 - 2011}

The trend in each season was for heavy or light machine treatments to have lower disease incidence than the control (Table 3). Hand thinning did not significantly reduce the incidence compared to the control within any season.

Table 3 Effect of method of grape-vine thinning on incidence of botrytis bunch rot in 2009, 2010 and 2011. Values are mean $\%$ of bunch infected.

\begin{tabular}{lccc}
\hline Thinning treatment & \multicolumn{3}{c}{ Assessment date } \\
\hline & 20 March & 9 April & 12 April \\
& 2009 & 2010 & 2011 \\
\cline { 2 - 4 } Un-thinned control & $40.0 \mathrm{~b}$ & $32.4 \mathrm{~b}$ & $43.3 \mathrm{~b}$ \\
Hand thinning & $35.6 \mathrm{~b}$ & $37.4 \mathrm{~b}$ & $45.6 \mathrm{~b}$ \\
Light machine thinning & $18.3 \mathrm{a}$ & $20.8 \mathrm{a}$ & $28.3 \mathrm{a}$ \\
Heavy machine thinning & $18.9 \mathrm{a}$ & $15.8 \mathrm{a}$ & $23.9 \mathrm{a}$ \\
$P$-value & $<0.001$ & $<0.001$ & $<0.001$ \\
\hline
\end{tabular}

$P$-values are from analysis using a binomial generalised linear model. Means within a date with different letters are significantly different (5\% LSD comparisons).

\section{Disease severity 2009 - 2011}

Seasonal differences in harvest botrytis severity were observed both within and between treatments (Table 4). In 2009, no significant differences were observed between any of the treatments. In 2010, harvest severity was significantly lower in the heavy machine-thinned fruit compared to the control and hand thinning, while severity for the light thinning treatment was significantly lower than the handthinned treatment. In 2011, botrytis severity at harvest for both the light and heavy machine-thinned treatments was significantly lower than the control; severity for the heavy machine-thinned grapes was also significantly lower than the hand-thinned grapes.

Table 4 Effect of method of grape-vine thinning on severity of botrytis bunch rot in 2009, 2010 and 2011. Values are mean $\%$ of bunch infection.

\begin{tabular}{lccc}
\hline $\begin{array}{l}\text { Thinning } \\
\text { treatment }\end{array}$ & \multicolumn{3}{c}{ Assessment date } \\
\hline & $\begin{array}{c}\text { 20 March } \\
\mathbf{2 0 0 9}\end{array}$ & $\begin{array}{c}\mathbf{9} \text { April } \\
\mathbf{2 0 1 0}\end{array}$ & $\begin{array}{c}\mathbf{1 2} \text { April } \\
\mathbf{2 0 1 1}\end{array}$ \\
\cline { 2 - 4 } $\begin{array}{l}\text { Un-thinned } \\
\text { control }\end{array}$ & 1.4 & $0.9 \mathrm{bc}$ & $2.8 \mathrm{c}$ \\
$\begin{array}{l}\text { Hand thinning } \\
\text { Light machine } \\
\text { thinning }\end{array}$ & 1.1 & $1.5 \mathrm{c}$ & $2.4 \mathrm{bc}$ \\
$\begin{array}{l}\text { Heavy machine } \\
\text { thinning }\end{array}$ & 0.8 & $0.6 \mathrm{ab}$ & $1.2 \mathrm{ab}$ \\
$P$-value & 0.4 & $0.4 \mathrm{a}$ & $0.8 \mathrm{a}$ \\
\hline
\end{tabular}

$P$-values are from analysis of variance on logit-transformed data. Within a column, means with different letters are significantly different (5\% LSD comparisons).

\section{Berry susceptibility - 2011}

Overall, the incidence of botrytis on individual berries in 2011 was largely dependent on whether the berries had been inoculated with $B$. cinerea or not $(P<0.001$; Table 5). However, there was also a significant three-way interaction among the treatments (inoculation $\times$ thinning $\times$ wounding, $P=0.045$ ). This result occurred because there

Table 5 Percentage of grape berries that had $B$. cinerea present after the grape vines received a thinning treatment and the berries either did or did not receive wounding and/ or inoculation treatments in 2011.

\begin{tabular}{|c|c|c|c|}
\hline \multirow{2}{*}{$\begin{array}{l}\text { Thinning } \\
\text { treatment }\end{array}$} & \multicolumn{3}{|c|}{ Botrytis cinerea (\%) } \\
\hline & Wounded & Non-inoculated & Inoculated \\
\hline $\begin{array}{l}\text { Un-thinned } \\
\text { control }\end{array}$ & No & $1.1 \mathrm{a}$ & $91.1 \mathrm{c}$ \\
\hline $\begin{array}{l}\text { Un-thinned } \\
\text { control }\end{array}$ & Yes & $1.5 \mathrm{a}$ & $94.5 \mathrm{c}$ \\
\hline $\begin{array}{l}\text { Heavy machine } \\
\text { thinned }\end{array}$ & No & $2.6 \mathrm{a}$ & $74.9 \mathrm{~b}$ \\
\hline $\begin{array}{l}\text { Heavy machine } \\
\text { thinned }\end{array}$ & Yes & $1.8 \mathrm{a}$ & $94.8 \mathrm{c}$ \\
\hline
\end{tabular}


were no significant differences among the wounding and thinning treatments when berries were not inoculated. However, when berries were inoculated, the heavy-thinned unwounded berries had less botrytis bunch rot than the same field treatment with wounding or the control with or without wounding.

\section{Debris incubation - $\mathbf{2 0 1 1}$}

Heavy machine thinning reduced the amount of debris within the bunches (Table 6), and the amount of B. cinerea sporulation in this debris when incubated was also less. However, the relative proportion of the debris that developed $B$. cinerea sporulation was unaffected by thinning treatment.

Table 6 Comparison of heavy thinning and un-thinned control on amount of debris present and observed infection by Botrytis cinerea following incubation in 2011.

\begin{tabular}{lccc}
\hline $\begin{array}{l}\text { Thinning } \\
\text { treatment }\end{array}$ & $\begin{array}{l}\text { Debris } \\
\text { (pieces/ } \\
\text { bunch) }\end{array}$ & $\begin{array}{l}\text { Debris with } \\
\text { B. cinerea } \\
\text { (pieces/ } \\
\text { bunch) }\end{array}$ & $\begin{array}{l}\text { \% of debris } \\
\text { with } \\
\text { B. cinerea }\end{array}$ \\
\hline $\begin{array}{l}\text { Un-thinned } \\
\text { control }\end{array}$ & 34.5 & 6.2 & 18.2 \\
$\begin{array}{l}\text { Heavy machine } \\
\text { thinned }\end{array}$ & 20.6 & 3.1 & 15.2 \\
$P$-value & 0.019 & 0.025 & 0.24 \\
\hline
\end{tabular}

$P$-values are from Student t-tests performed on the means of 25 bunches from each of $n=6$ replicates. Debris that produced spores during incubation was considered infected and recorded as a single piece of debris with infection. The percentage of debris in each bunch with $B$. cinerea was calculated on a bunch-by-bunch basis.

\section{DISCUSSION}

Currently, available chemical bunch rot controls are primarily focused on early-season actions by necessity, because lateseason chemical options are limited to avoid residues in wine. Mechanical thinning as a management option could provide a mid-season alternative. The first two years of the project demonstrated that mechanical thinning resulted in the same or lower observed botrytis bunch rot severity as found in un-thinned or hand-thinned vines (significantly lower severity in 2010). Of particular interest was the possible mechanism of the effect mechanical thinning had on botrytis bunch rot at harvest. The investigation of the three hypothesised mechanisms: (1) a more open bunch; (2) berries that may be less susceptible to infection; and (3) removal of debris from the bunch, in the third year (2011) provided some indication of significant differences between the treatments for berry infection rates and total infected debris in the bunch at harvest.

(1) Bunch openness as a calculated volume from the longest and widest points has been suggested as a method of comparing bunches between cultivars and seasons (Shavrukov et al. 2004). The calculation method used here also allows results to be compared with other published findings investigating changes in bunch structure and botrytis bunch rot (Mundy et al. 2014). The concept is that a more open bunch: does not hold debris; allows better air movement for drying; and improves spray penetration allowing better control of Botrytis cinerea build up on nonberry tissues between flowering and fruit ripening.

Heavy mechanical thinning significantly reduced the bunch weight and the actual volume of the bunch as well as the calculated volume which matched the observation that bunches with this treatment looked more open. When the ratio of calculated to actual volume was compared for the two treatments where both methods had been used, no significant difference in ratio was observed implying that while the actual volume of the bunch might be smaller than the calculated, the amount of overestimation was consistent and the faster calculation method can be used to compare how open the bunch for this study. However, for the Sauvignon blanc grapes in Marlborough, we have previously noted issues with this method caused by the large within-vine variation in bunch shape and size, resulting in differences in volume within the same vine (Mundy et al. 2014). Plotting the data indicated that both treatments resulted in bunches with a large range of volumes, making robust comparisons between treatments difficult (data not shown). Further analysis of individual bunch disease intensities, and the extent to which this is related to bunch weight and/or volume across all thinning treatments is required.

(2) The berry bioassay indicated that berries from heavily mechanically thinned vines that were not wounded were less susceptible to $B$. cinerea infection following artificial inoculation than wounded berries. The observed reduction in susceptibility was only $20 \%$ despite the experiment being conducted under ideal conditions for the fungus for seven days and with a high spore loading. Published research has indicated that environmental changes (e.g. increased fruit exposure) can increase the thickness of the epidermis of grape berries, which in turn may be associated with a reduction in the susceptibility of berries to Botrytis cinerea (Verdenal et al. 2018). In experiments reported here, the susceptibility of wounded berries from the same vines to infection would suggest that a difference in the skin or outer layer of the berry following heavy machine thinning may be responsible for the observed difference. It can be inferred from the low incidence of disease on uninoculated berries (either wounded or not) that latent infection was not present in the berries used in the assay. The reduced susceptibility of individual inoculated berries without wounding in the heavy machine treatment has been further investigated in subsequent experiments to determine what chemical changes to berry physiology result from machine thinning treatments (Schwendel et al. 2021). The researchers observed distinct changes in primary berry metabolism of green berries at shaking as well as significant secondary metabolism berry changes as fruit soften later in development. Shaken vines accumulated phenolic compounds as well as amino and fatty acids near the skin of the berry. Their experiment was conducted on Sauvignon blanc grapes in Marlborough using the same shaking methods. Microscope studies of skin thickness are also underway but not yet published. 
(3) Both total debris per bunch and the amount of debris infected with $B$. cinerea per bunch were significantly lower in bunches from vines on the heavily mechanically thinned vines compared with un-thinned vines. These differences may indicate that heavy mechanical thinning reduced the harvest disease scores by reducing inoculum in the bunch. Additional studies will be required to determine if the reduction in debris or $B$. cinerea-infected debris per bunch accounts for the decreased harvest botrytis incidence and severity. International research has shown that flower debris and latent infections can be important for bunch rot epidemics (Keller et al.2003, Molitor et al. 2015). The viticulture industry already uses other methods such as mechanical blowers to try and remove debris from grape bunches. Investigations to determine if debris removal alone can reduce the field severity of observed disease in the same way as mechanical thinning would be useful. In general, the importance of debris in the epidemic of botrytis bunch rot within crops has been discussed in detail (Elmer and Michailides 2007). Under New Zealand grape production conditions, studies have shown the importance of debris as a source of spores for later infection of the berry when it is susceptible (Jaspers et al. 2016; Mundy et al. 2012). While reports of botrytis bunch rot in mechanical thinning for crop control are not numerous, our results are consistent with those from Spain looking at red grapes (Tardaguila et al. 2012). In that study, the authors recorded botrytis bunch rot incidence as they accessed bunches so that those bunches with botrytis bunch rot could be excluded from calculations of yield. In the Spanish study, all mechanical treatments reduced incidence compared to the control regardless of timing or method of yield reduction.

Our original hypothesis was that mechanical thinning would result in more disease due to infection of debris resulting from the thinning. The lack of a significant difference in percentage of debris that was infected from either heavy machined thinning or no thinning in 2011 indicates this was not the case. However, there was a period of dry weather following thinning that year. Debris incubations of material from vines thinned before botrytis infection periods would be useful to determine if this approach increased the percentage of debris infected. Investigations of bunch debris at the time of thinning would determine if the lower numbers of debris pieces in the thinned bunches is due to direct shaking of the bunch during the thinning or the removal of individual berries allowing debris to fall from the bunch over time before harvest.

Regardless of the mechanism of reduced risk of disease in the field, we also need to consider that possible changes in berry metabolism may result in changes to the wine made from the grapes. In related studies, late-season trauma to berries during harvesting was investigated to determine if pathogenesis-related proteins and phenolic extraction of juice increased with mechanical processing and harvesting (Tian et al. 2017). Both sets of compounds can be a problem during production of white wines; if present they require additional winemaking treatment to stop haze-forming in the finished wine.

Provided that there are no adverse effects on fruit composition and wine quality, the lower cost of mechanical thinning has the potential to provide a significant advantage over hand thinning of white grapes. When trials were started it was thought that that damage to the fruit during the thinning process may result in increased botrytis severity. However, we now suggest that mechanical thinning may have multiple effects on the bunch that, when combined, result in lower observed disease. In the 2011 season, the control treatment had the highest observed disease severity of the three seasons observed. During this season, bunch severity in the heavy-thinned treatment was significantly lower when compared to the hand-thinned or control treatments providing some confidence that the mechanical thinning can reduce harvest disease scores. Extending the investigation to different sites and cultivars will determine if the differences in disease between treatments are consistently observed. Effective machine thinning on other cultivars has already been reported (Petrie \& Clingeleffer 2006; Tardaguila et al. 2008; Tardaguila et al. 2012; Diago et al. 2010) hence investigation of disease management using machine shaking in other cultivars in New Zealand is the next logical step to developing this residue-free method of reducing risk of disease for growers.

\section{ACKNOWLEDGEMENTS}

Funding for this project was provided by New Zealand Winegrowers (NZW 08-334). The research was conducted with assistance of Emma Sherman, Sharlene Haycock, Victoria Raw and Megan Gee at Plant \& Food Research.

\section{REFERENCES}

Bates TR 2017. Mechanical crop control in New York 'Concord' vineyards target desirable crop load levels. Acta Horticulturae 1177: 259-264. https://doi. org/10.17660/ActaHortic.2017.1177.37

Beresford RM, Evans KJ, Wood PN, Mundy DC 2006. Disease assessment and epidemic monitoring methodology for bunch rot (Botrytis cinerea) in grapevines. New Zealand Plant Protection 59: 355-360. https://doi. org/10.30843/nzpp.2006.59.4594

Diago MP, Vilanova M, Tardaguila J 2010. Effects of timing of manual and mechanical early defoliation on the aroma of Vitis vinifera L. Tempranillo wine. American Journal of Enology and Viticulture 61: 382-391.

Elmer PAG, Michailides TJ 2007. Epidemiology of Botrytis cinerea in orchard and vine crops. In: Elad Y, Williamson B, Tudzynski P, Delen N Eds. Botrytis: Biology, Pathology and Control. Kluwer Academic Publishers ;Springer, Dordrecht, The Netherlands. Pp. 243-272. https://doi. org/10.1007/978-1-4020-2626-3 14

Geller JP, Kurtural SK 2013. Mechanical canopy and cropload management of Pinot gris in a warm climate. American Journal of Enology and Viticulture 64: 65-73. https://doi.org/10.5344/ajev.2012.12045

Hoksbergen T 2010. Impact of Botrytis cinerea on vineyard returns and wine quality. In Grape Day seminar, Marlborough, New Zealand Winegrowers. Marlborough, New Zealand Winegrowers June 2021. 
Jaspers MV, Seyb AM, Trought MCT, Balasubramaniam R 2013. Overwintering grapevine debris as an important source of Botrytis cinerea inoculum. Plant Pathology 62: 130-138. $\quad$ https://doi.org/10.1111/j.13653059.2012.02631.x

Keller M, Viret O, Cole FM 2003. Botrytis cinerea infection in grape flowers: defense reaction, latency, and disease expression. Phytopathology 93(3): 316-22. https://doi. org/10.1094/PHYT0.2003.93.3.316

Molitor, D. Hoffmann, L. Beyer, M 2015. Flower debris removal delays grape bunch rot epidemic. American Journal of Enology and Viticulture 66(4): 548-553 https://doi.org/10.5344/ajev.2015.15019

Mundy DC, Beresford RM 2007. Susceptibility of grapes to Botrytis cinerea in relation to berry nitrogen and sugar concentration. New Zealand Plant Protection 60: 123127. https://doi.org/10.30843/nzpp.2007.60.4636

Mundy DC, Agnew RH, Wood PN 2012. Grape tendrils as an inoculum source of Botrytis cinerea in vineyards a review. New Zealand Plant Protection 65: 218-227. https://doi.org/10.30843/nzpp.2012.65.5373

Mundy DC, Haycock SR, Raw V, Agnew RH, Sherman E, McLachlan ARG, Hagerty GC 2014. Effects of chemical and natural product treatments on bunch openness and botrytis bunch rot in Sauvignon blanc grapes. New Zealand Plant Protection 67: 157-167. https://doi. org/10.30843/nzpp.2014.67.5747

Neal SM, Trought MCT, Mundy DC, Albright A, McLachlan A, Allen M, Pecchenino D 2016. New opportunities for sustainable grape thinning. Poster presented at the 16th Australian Wine Industry Technical Conference. Adelaide, SA.

Petrie PR, Clingeleffer PR 2006. Crop thinning (hand versus mechanical), grape maturity and anthocyanin concentration: outcomes from irrigated Cabernet Sauvignon (Vitis vinifera L.) in a warm climate. Australian Journal of Grape and Wine Research 12: 21-29. https:// doi.org/10.1111/j.1755-0238.2006.tb00040.x

Pool RM, Dunst DC, Crowe H, Hubbard GE, Howard GE, DeGrolier G 1993. Predicting and controlling crop on machine or minimal pruned grapevines. Proceedings of 2nd Nelson J. Shaulis Grape Symposium: Pruning mechanization and crop control: 3145. https://ecommons.cornell.edu/bitstream/ handle/1813/17512/1993\%202nd\%20Shaulis $\% 20$ Symposium.pdf? sequence $=3$ \&isAllowed $=y$

Schwendel BH, Anekal PV, Zarate E, Bang KW, Guo G, Grey AC, Pinu FR 2021. Mass spectrometry-based metabolomics to investigate the effect of mechanical shaking on Sauvignon blanc berry metabolism. Journal of Agricultural and Food Chemistry 69: 4918-4933. https://doi.org/10.1021/acs.jafc.1c00413

Shavrukov YN, Dry IB, Thomas MR 2004. Inflorescence and bunch architecture development in Vitis vinifera L. Australian Journal of Grape and Wine Research 10: 116-124. https://doi.org/10.1111/j.1755-0238.2004. tb00014.x
Tardaguila J, Blanco JA, Poni S, Diago MP 2012. Mechanical yield regulation in winegrapes: comparison of early defoliation and crop thinning. Australian Journal of Grape and Wine Research 18: 344-352. https://doi. org/10.1111/j.1755-0238.2012.00197.x

Tardaguila J, Petrie PR, Poni S, Diago MP, Martinez de Toda F 2008. Effects of mechanical thinning on yield and fruit composition of tempranillo and grenache grapes trained to a vertical shoot-positioned canopy. American Journal of Enology and Viticulture 59: 412-417.

Tian B, Harrison R, Morton J, Jaspers MV, Hodge S, Grose C, Trought MCT 2017. Extraction of pathogenesisrelated proteins and phenolics in Sauvignon blanc as affected by grape harvesting and processing conditions. Molecules 22: 1164. https://doi.org/10.3390/ molecules22071164

Trought MCT 2005. Fruitset - possible implications on wine quality. In: deGaris K, Dundon C, Johnstone R, Partridge S Eds. Transforming flowers to fruit. Australian Society of Viticulture and Oenology, Mildura, Australia. Pp. 32-36.

Trought MCT, Neal SM, Greven MM, Mundy DC, Raw V, McLachlan A 2015. Reduced berry size and Botrytis tolerance through trauma to the vine. New Zealand WineGrower 90: 68-71.

Trought MCT, Neal SM, Mundy DC, Grose C, Beresford MK, McLachlan A, Allen M 2014. New opportunities for sustainable grape thinning - what have we learned after five years of research? New Zealand WineGrower 87: 131-133.

Verdenal, T. Zufferey, V. Dienes-Nagy, A. Belcher, S. Lorenzini, F. Rösti, J. Koestel, C. Gindro, K. Spring, J-L 2018. Intensity and timing of defoliation on white cultivar Chasselas under the temperate climate of Switzerland. OENO One 52: 93-104. https://doi.org/10.20870/oenoone.2018.52.2.2158 